\title{
Population dynamics of the migratory fish Prochilodus lineatus in a neotropical river: the relationships with river discharge, flood pulse, El Niño and fluvial megafan behaviour
}

\author{
Marinke J. M. Stassen ${ }^{1,2}$, Max W. P. M. van de Ven ${ }^{2,3}$, Tjisse van der Heide ${ }^{1}$, \\ Marco Antonio Guerrero Hiza ${ }^{4}$, Gerard van der Velde ${ }^{5,8}$ and Alfons J. P. Smolders ${ }^{2,3,6,7}$
}

\begin{abstract}
The relative importance of flood pulse dynamics and megafan behaviour for the Sábalo (Prochilodus lineatus) catches in the neotropical Pilcomayo River is studied. The Sábalo catches can mainly be explained by decreased river discharges in the preceding years resulting in smaller inundated areas during rainy season floods and thereby in a decreased area of feeding grounds for the fishes. The decreased river discharges and the related decline of Sábalo catches in the 1990's can be linked to the 90-95 El Niño event. In 2007 the Sábalo catches were comparable to the catches before the "El Niño" event. The connectivity (continuity) between the main river and flood plain areas, which is influenced by sedimentation processes, is also of great importance and very probably plays a more important role since the late 1990's.
\end{abstract}

Se ha estudiado la importancia relativa de la dinámica del pulso de inundación y el comportamiento del sistema megafan para las capturas del Sábalo (Prochilodus lineatus) en el río Pilcomayo. Las capturas del Sábalo puede explicarse fundamentalmente por los bajos caudales del río en los años anteriores, resultando en menores superficies de las zonas inundadas durante la temporada de lluvia y por lo tanto en una área menor de alimentación para los peces. La disminución del caudal del río y la declinación relativa de capturas de Sábalo en los años 1990 pueden estar relacionadas con el 90-95 evento de El Niño. En 2007, la captura de Sábalo fue comparable a las capturas antes del evento de "El Niño". La conectividad (continuidad) entre el río principal y las llanuras aluviales, que son influenciadas por los procesos de sedimentación, son también de gran importancia y muy probablemente juegan un papel muy importante desde finales de los años ' 90 .

Key words: Sedimentation, Climate change, Sábalo, Gonadal development, Flood Pulse Concept (FPC).

\section{Introduction}

The Flood Pulse Concept (FPC) emphasizes the importance of the dynamic interaction between land and water as a force which strongly enhances biological productivity (Junk et al., 1989; Bayley, 1991, 1995; Ward \& Stanford, 1995; Baldwin \& Mitchell, 2000). According to the FPC, the production of riverine animal biomass, such as migratory fishes, derives directly or indirectly from organic matter production within the floodplain and not from downstream transport of organic matter (Junk et al., 1989). In floodplain rivers, fish production tends to be strongly related to the intensity of flooding (Welcomme \& Hagborg, 1977; Welcomme, 1979, 1995; Moses, 1987; Payne \& Harvey, 1989; Laë, 1992; de Graaf, 2003; Welcomme et al., 2006).

The South-American Pilcomayo River is strongly influenced by the natural hydrological cycle. The upper and middle parts of the river have as yet not been regulated by dams or hydrological-technical works. Therefore the river provides an excellent case to examine the impact of flood pulse dynamics on the population dynamics of migratory fishes under natural circumstances.

\footnotetext{
${ }^{1}$ Department of Environmental Sciences, Radboud University Nijmegen, Heijendaalseweg 135, 6525 AJ Nijmegen, The Netherlands. m.stassen@science.ru.nl (MJMS), t.van.der.heide@rug.nl (MWPMV)

${ }^{2}$ Foundation 'Los Amigos del Pilcomayo', P.O. Box 47, Calle la Paz 167, Villa Montes - Dep. Tarija, Bolivia. pilcomayo@gmail.com ${ }^{3}$ Department of Aquatic Ecology and Environmental Biology, Radboud University Nijmegen, Heijendaalseweg 135, 6525 AJ Nijmegen, The Netherlands. a.smolders@science.ru.nl(AJPS)

${ }^{4}$ ADEPESCA, Villa Montes, Bolivia.

${ }^{5}$ Department of Animal Ecology and Ecophysiology, Aquatic Animal Ecology Section, Radboud University Nijmegen, Heijendaalseweg 135, 6525 AJ Nijmegen, The Netherlands. g.vandervelde@science.ru.nl

${ }^{6}$ Ambio Chaco, Villa Montes, Bolivia.

${ }^{7}$ B-WARE Research Centre, Toernooiveld 1, 6525 ED Nijmegen, The Netherlands. a.smolders@b-ware.eu

${ }^{8}$ National Natural History Museum Naturalis, P.O. Box 9517, 2300 RA Leiden, The Netherlands. g.vandervelde@science.ru.nl
} 
The Pilcomayo River is populated by various migratory fish species, which have an important nutritional and commercial value for the local indigenous human population. The Sábalo, Prochilodus lineatus, (Characiformes, Prochilodontidae) is the most abundant migratory fish species in the Pilcomayo River (Bayley, 1973; Payne \& Harvey, 1989; Smolders et al., 2000, 2002). Prochilodus lineatus is a detritivorous fish (Bowen, 1983; Bowen et al., 1984; Bayo \& Cordiviola de Yuan, 1996; Fugi et al., 1996; Lopes et al., 2007) that feeds in the Pilcomayo floodplains of the lower Chaco (Bayley, 1973; Payne \& Harvey, 1989), where as a result of the decomposition of terrestrial and aquatic vegetation during flooding and flood recession the levels of organic detritus tend to be high (Cordiviola de Yuan, 1992; Bayley, 1995). This might explain the dominance of $P$. lineatus in such flood plains in the Paraná region, where the species may account for up to 90\% of the fish biomass (Bonetto et al., 1969; Bayley, 1973; Cordiviola de Yuan, 1992). Prochilodus species fulfil important functional roles in neotropical riverine ecosystems by ingesting and processing large amounts of sediment. Detritus is a crucial pathway in energy and nutrient fluxes in ecosystems and loss of detritivores could therefore strongly influence ecosystem functioning (Bowen, 1983; Flecker, 1996; Taylor et al., 2006).

The considerable decrease of Sábalo catches in the Pilcomayo River during the 1990's was an important concern. In 1993, P. lineatus was even listed as a vulnerable species by the Bolivian government. Various explanations have been put forward to explain the decline of $P$. lineatus in the river during the 1990's. Of these explanations contamination of the river with heavy metals from mining activities in the upper reaches of the river (near Potosí) has received most attention (Edwards, 1996; Garcia-Guinea \& Huascar, 1997; Medina Hoyos, 1998; Hudson-Edwards et al., 2001; Miller et al., 2002; Smolders et al., 2003). The mining region near the city of Potosí forms part of the Bolivian Pilcomayo catchment (Fig. 1). Mining activities started in the $16^{\text {th }}$ century at 'Cerro Rico de Potosí'. In 1985 the Crushing-Grinding-Flotation method was introduced to recover Lead $(\mathrm{Pb})$ and Zinc $(\mathrm{Zn})$. At present, there are as many as 40 processing plants ('Ingenios'), all working with the flotation process, operating in or immediately adjacent to the city of Potosí. These plants emit slurries containing highly alkaline (pH 10-12) water and high levels of unrecovered metals in the local streams. Ultimately, these streams drain into the Tarapaya River which is a tributary to the Pilcomayo River. Research revealed, however, that it is highly unlikely, that the measured levels of metal contamination of the lower parts of the river (Hudson-Edwards et al., 2001; Smolders et al., 2003) could have been responsible for the decline of the Sábalo in the 1990's (Smolders et al., 2002). The intensity of fishing has strongly increased but can neither explain the decline of the Sábalo in the nineties (Payne \& Harvey, 1989; Smolders et al., 2002). In the Pilcomayo River, however, flood pulse dynamics may be expected to have an overriding effect on fish production and dynamics (Krykhtin, 1975; Welcomme, 1979; Welcomme et al., 2006).

The main aim of this paper is to reveal whether the general
FPC applies for the abundance and timing of the reproduction of $P$. lineatus in the Pilcomayo River, where sedimentation processes have interrupted the former direct connection between the lower reaches of the Pilcomayo River and the Paraguay River due to the presence of an active fluvial megafan system. This system is formed as the Pilcomayo River exits the Andes range and enters the adjacent Chaco basin, allowing the river to migrate laterally and to deposit huge fanshaped bodies of sediment.

The main research questions of the present study are: a) Is river discharge a major force for the abundance of Prochilodus lineatus in the Pilcomayo River? b) Does annual variability of river discharge have an effect on the timing of the reproduction of Prochilodus lineatus?

\section{Material and Methods}

\section{Study area}

The Pilcomayo River, a tributary to the large 'La Plata' system, has a catchment basin area of approximately 272,000 $\mathrm{km}^{2}$. It arises in the Bolivian Andes (Cordillera Oriental, ca. $5000 \mathrm{~m}$ a.s.l.) and cuts down through the Andes, through an inaccessible terrain with rapids and narrow canyons, until it reaches the Chaco plain near the town of Villa Montes (ca. $400 \mathrm{~m}$ a.s.1.). The Andean part of the river has a length of ca. $500 \mathrm{~km}$ and a mean slope of 10 per mill. The river then flows southward through the Chaco, where it soon forms the natural frontier between Argentina and Paraguay before it eventually joins the Paraguay River just north of the town of Asunción (Fig. 1). This lower stretch of the river has a total length of almost $1000 \mathrm{~km}$ and a very low mean slope of only 0.2 per mill. The river is strongly influenced by the hydrological cycle, which is driven by the differences in rainfall between the dry (May to October) and the wet (November to April) seasons (Bayley, 1973; Payne \& Harvey, 1989; Smolders et al., 2002, 2004). The lower reaches are alternately affected by inundation and drought. Near the town of Villa Montes migrating fishes are exploited commercially by means of seine nets, fish traps (Fig. 2) and throwing nets.

\section{Data analysis}

In general fishing activities in river systems are diffuse and it is hard to register catches more or less completely. In the case of the Pilcomayo River, however, the fish have to pass through a narrow canyon with strong currents. It is along the shores of this canyon that fish traps (Fig. 2) are located, which function day and night and are very efficient. Since the 1980's an effort was made by the authorities to make accurate recordings of the amounts of fish extracted from the river, for tax reasons. This was done by registrations of the amounts of fish transported from all the commercial fishing sites in the surroundings of Villa Montes. Therefore the official estimations of Sábalo catches in the Pilcomayo River are remarkably good compared to many other rivers.

Official estimations of total annual Sábalo ( $P$. lineatus) catch in Villa Montes and data on river discharges were 


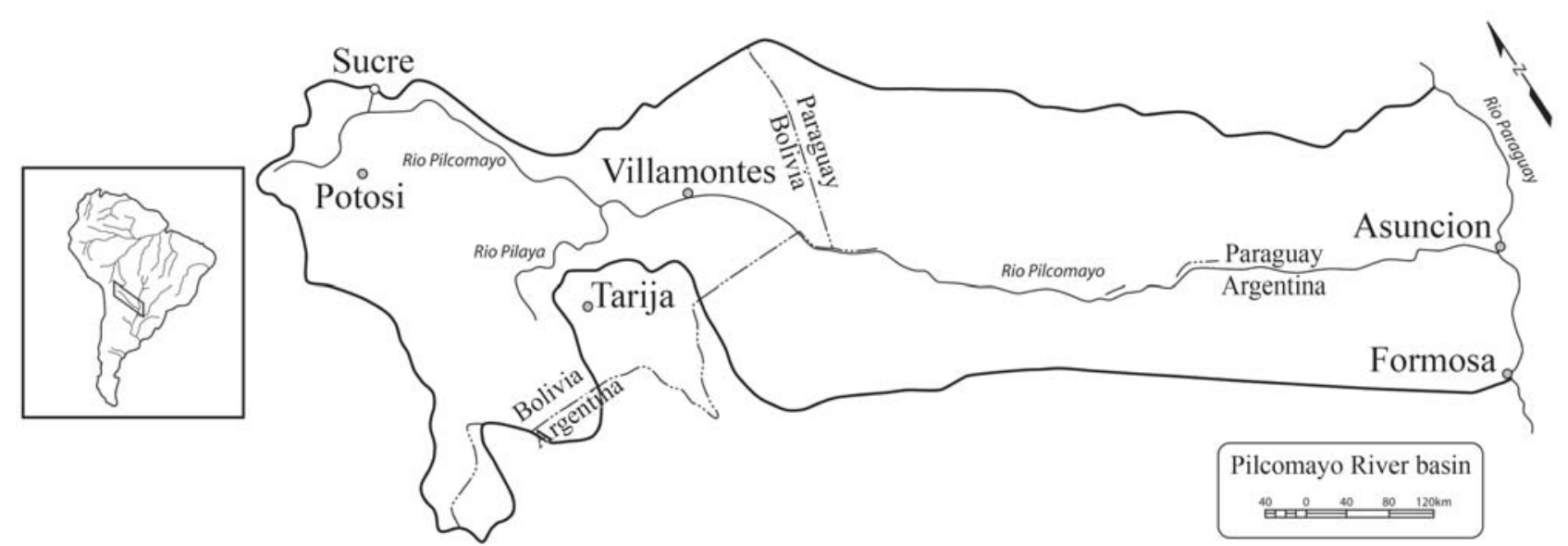

Fig. 1. Map of the Pilcomayo River basin.

obtained from Proyecto Pilcomayo (Tarija, Bolivia). These data were analyzed by multiple linear regression with backward deletion of variables (SPSS version 15). The discharge of the seven preceding years (Y1, Y2, Y3, Y4, Y5, Y6 and Y7) plus the current year ( $\mathrm{Y} 0)$ were included in the analyses as independent variables. Sábalo catch was the dependent variable. The criterion for the probability of F-to-remove was $\geq .100$ ).

\section{Gonadal development}

Data on gonad development where derived from Guerrero Hiza (1998). On six different dates in 1998 (May 22, June 19, August 7, August 25, September 11 and September 30) 25 fishes were obtained from fish traps in the Pilcomayo canyon near Villa Montes, and the stage of gonadal maturation was analyzed for each fish. To each fish one of the following stages (I to V) was attributed. Stage I (inactive stage): Ovaries are small. No oocyte is visible to the naked eye. Stage II (recovering stage): Few oocytes are visible to the naked eye. There are few yolks. Stage III (early maturing stage): Most of the oocytes are visible to the naked eye. There are some yolks in these oocytes. Stage IV (late maturing stage): All the

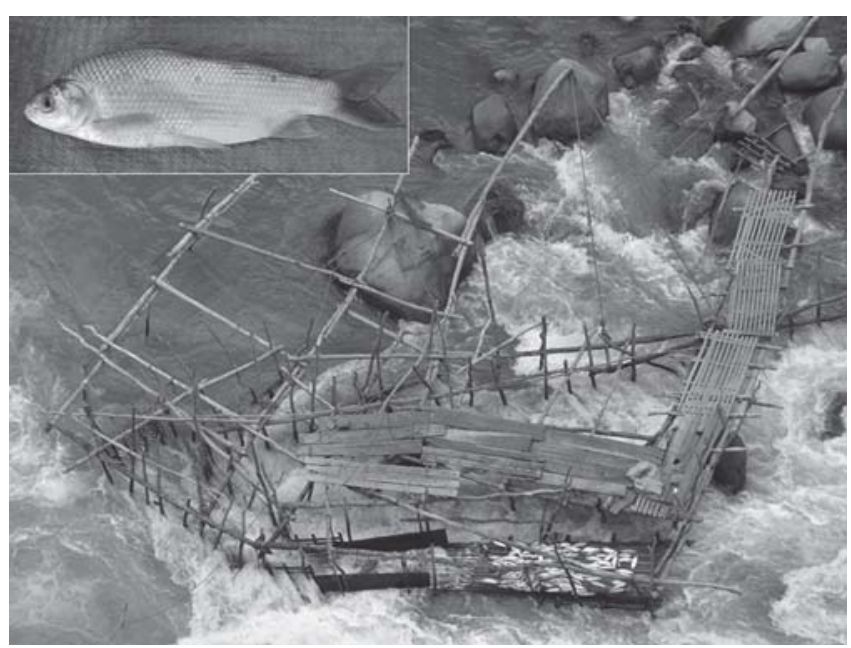

Fig. 2. Fish trap in the Pilcomayo River. In the inset the Sábalo (Prochilodus lineatus). oocytes are visible to the naked eye. There are many yolks in the oocytes. Stage V (mature stage): Many mature oocytes are released from their follicles into the ovarian cavity. The oocytes could flow out through the genital opening when the abdomen is gently pressed. The mean value for the gonadal development stage of the 25 fishes was calculated.

\section{Water chemistry}

From May 1998 until February 1999 samples of the Pilcomayo River were collected regularly at Villa Montes (Bolivia). Immediately after collection temperature was measured and $\mathrm{pH}$ and bicarbonate $\left(\mathrm{HCO}_{3}^{-}\right)$were determined, after which samples were filtered $(0.45 \mu \mathrm{m})$. Next $1 \mathrm{ml}$ of nitric acid per $100 \mathrm{ml}$ water was added, after which the samples were stored in pre-washed polyethylene containers at $20^{\circ} \mathrm{C}$ until analysis. For anion analyses samples were filtered and $60 \mathrm{mg}$ citric acid per $100 \mathrm{ml}$ water was added after which the samples were stored in pre-washed polyethylene containers at $-20^{\circ} \mathrm{C}$ until analysis (see Smolders et al., 2004). Total dissolved ion concentration was calculated from the analyses by adding up the concentrations of all cation and anions.

\section{Results and Discussion}

\section{Possible effects of the hydrochemical cycle on biota Intra-annual variation and reproduction}

At the onset of the dry season, Sábalo ( $P$. lineatus) appear in Villa Montes, because the fish reach the Andean region in their upstream migration. The peak of the Sábalo migration is observed in May. Only adult fish of at least 2 years old migrate. The young Sábalo (young-of-the-year (YOY)) remain in the flood plain area in the lower Chaco in Paraguay and Argentina to feed and had to survive the dry season in pools and oxbow lakes that retain water throughout the dry season (Bonetto et al., 1969; Cordiviola de Yuan, 1992). As there are no suitable food resources in the upper parts of the Pilcomayo River, the fish do not feed during their upstream migration and fully depend on their fat reserves (Bayley, 1973; Payne \& Harvey, 1989). When river discharges increase at the onset of the rainy season (October to January) the migrating Sábalo spawn 
their eggs in the open water of the main channel of the river in the foothills of the Andes (Bayley, 1973). The peak of reproduction falls in November-January (Mochek \& Pavlov, 1998). Similar migratory behaviour with spawning during periods of rising river water levels has been observed for Prochilodus lineatus in the lower Uruguay River (Espinach Ros et al., 1998) and for Prochilodus scrofa (=P. lineatus) in the Mogi-Guassu River (Godoy, 1959). An advantage of this particular spawning behaviour is that eggs and developing alevins are rapidly transported downstream towards the floodplain, where they are distributed by the rising water over the freshly inundated feeding grounds (Bayley, 1973; Cordiviola de Yuan, 1992; Araujo-Lima \& Oliveira, 1998; Welcomme et al., 2006).

In 1998, development of the Sábalo gonads was monitored in the Pilcomayo River by Guerrero Hiza (1998). Fig. 3 shows that the development of the gonads followed the gradual increase in aqueous total dissolved solids. The period in which spawning was observed was characterized by low dissolved solids contents following the onset of the rainy season (Fig. 3). Many other species from rivers that show a strong seasonal
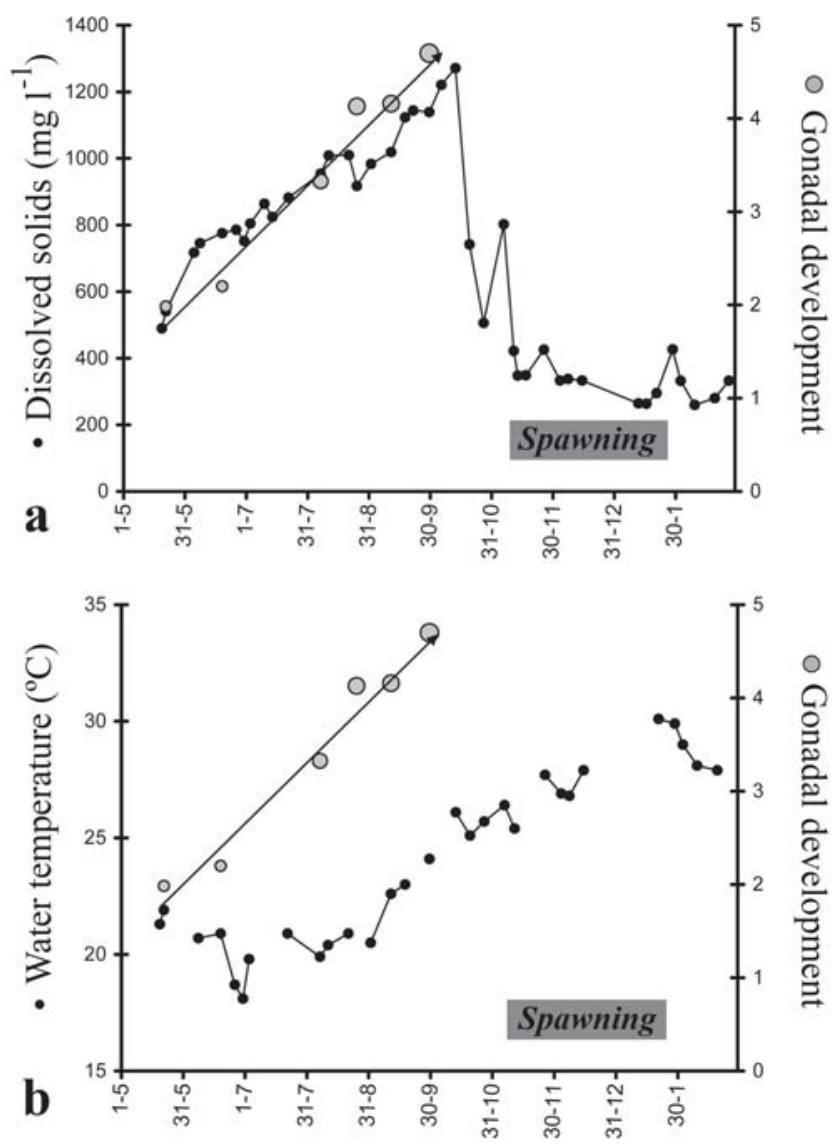

Fig. 3. Total dissolved solids concentration (TDS) in Pilcomayo River water (a) or water temperature (b) and gonadal maturation indices of Sábalo (Prochilodus lineatus) fish versus time (May 1998 until February 1999). The gonadal maturation indices are scaled from 1 to 6 in which 6 represents spawning. variation in discharge also show synchronized reproduction at the early wet season (e.g. Winemiller, 1989; Paugy, 2002; Welcomme et al., 2006).

In a highly dynamic system such as the Pilcomayo River, river discharge and aqueous major ion compositions and total dissolved solid concentrations typically show large variations during the year (Fig. 3). Current velocity is assumed to be an important trigger for spawning and migration for stream fish species (Lucas \& Barras, 2001; Welcomme et al., 2006). Macroion concentrations, however, might also play an important role by serving as a trigger for processes related to the reproduction of fish. For example, a strong drop of the conductivity at the onset of the rainy season has been shown to be responsible for the induction of spawning in the neotropical fishes Eigenmannia virescens (e.g. Kirschbaum, 1979) and Hoplosternum littorale (e.g. Ramnarine, 1995). Furthermore in Hoplosternum littorale increasing total dissolved solids serve as a stimulus for gonad development during the preceding dry season (Hostache et al., 1993). We propose that changes in water chemistry may trigger gonad development and spawning in $P$. lineatus in the Pilcomayo River. Interestingly, gonad development in 1998 was two months ahead of observed maturation indices in preceding years (Guerrero Hiza, 1998); this could be explained by the fact that during the very dry El Niño year 1998 (Smolders et al., 2000) high dissolved solid concentrations were reached much earlier than in 'normal' years. Water temperature did not appear to correlate with gonad development (Fig. 3b). We suggest that research regarding the effect of dissolved solid concentrations on gonad development should be considered for rivers with large fluctuations in river discharge.

\section{Inter-annual variation}

The Pilcomayo River is not only characterized by strong intra-annual variations but also by strong inter-annual variations in river discharge (Fig. 4a). Models predict that production in a particular year depends on the amount of water that remains in the flood plain after a flood (Welcomme, 1979), since the area of suitable fish nursery grounds is directly related to the flooded surface area (Benke, 2000). Hence, fish catches in floodplain rivers are frequently related to the extent of the floods in the preceding years (Krykhtin, 1975; Welcomme, 1979; Laë, 1992; Gomes \& Agostinho, 1997; Smolders et al., 2002; Welcomme et al., 2006). Dry years not only decrease the availability of feeding grounds but may also result in a lack of connectivity (continuity) between the elements of the flood plain (e.g. Junk et al., 1989; Welcomme et al., 2006). For instance, in dry years young fish are unable to migrate from the permanent lagoons and pools, where they survive the dry season, towards the highly nutritious waterland transition zones. Furthermore, the migration of adult fish towards the main channel is hampered, while desiccation and predation of juveniles by birds can also result in high mortality rates (Agostinho \& Zalewski, 1995).

By means of multiple linear regression, we obtained a remarkably strong relationship between Sábalo catch and river 


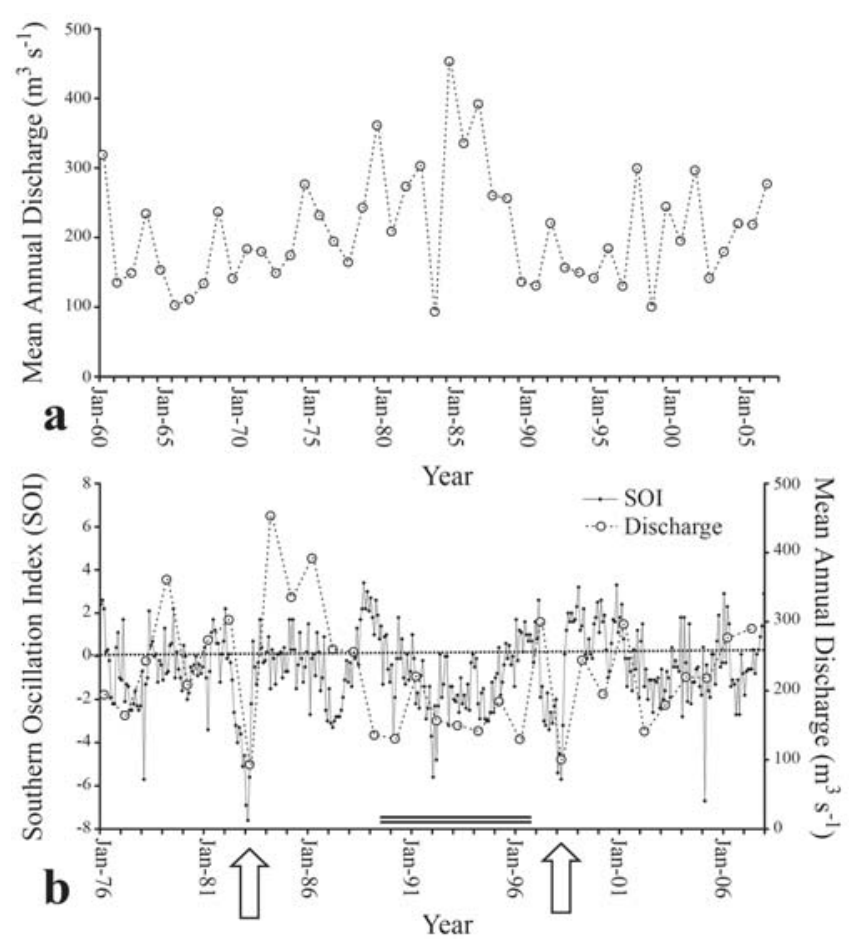

Fig. 4. (a) Mean annual discharge for the Pilcomayo River since 1960. The values were calculated for the hydrological year, which runs from October of the previous year until September of the current year. Data were obtained from Proyecto Pilcomayo (Tarija, Bolivia). (b) Mean monthly values of the Southern Oscillation Index (dots) and mean annual discharges of the Pilcomayo River (open circles), since 1976. Mean annual discharge values were calculated from data obtained from Proyecto Pilcomayo (Tarija, Bolivia). The values were calculated for the hydrological year, which runs from October of the previous year until September of the current year.

discharges of preceding years for the period 1980-1996 (adjusted $\mathrm{R}^{2}=0.94$ ) (Fig. 5, Table 1). Remarkably, the five preceding years had a significant effect on Sábalo catches although the Sábalo caught were two to three years old. Apparently there is a kind of memory effect playing a role as low or high productivity caused by low or high river discharges in the past has a significant effect on future generations. Apparently a strong year class caused by a high production and survival of eggs and alevins, can have a positive effect on the population size in many years that follow while the opposite will be true for weak year classes.

A decline of mean river discharges since the middle of the 1980 's was followed by a gradual decrease of Sábalo catches and the first half of the 1990's was characterized by very low river discharges and low corresponding Sábalo catches (Fig. 5a). The 'return of the Sábalo' after its collapse in the 1990's, coincides with the recovery of the mean discharge in the preceding years (Fig. 5a). However, since 1996 the relationship between river discharge and Sábalo catches has changed considerably. Now, only the three preceding years are significantly contributing, but still $70 \%$ of the variation can
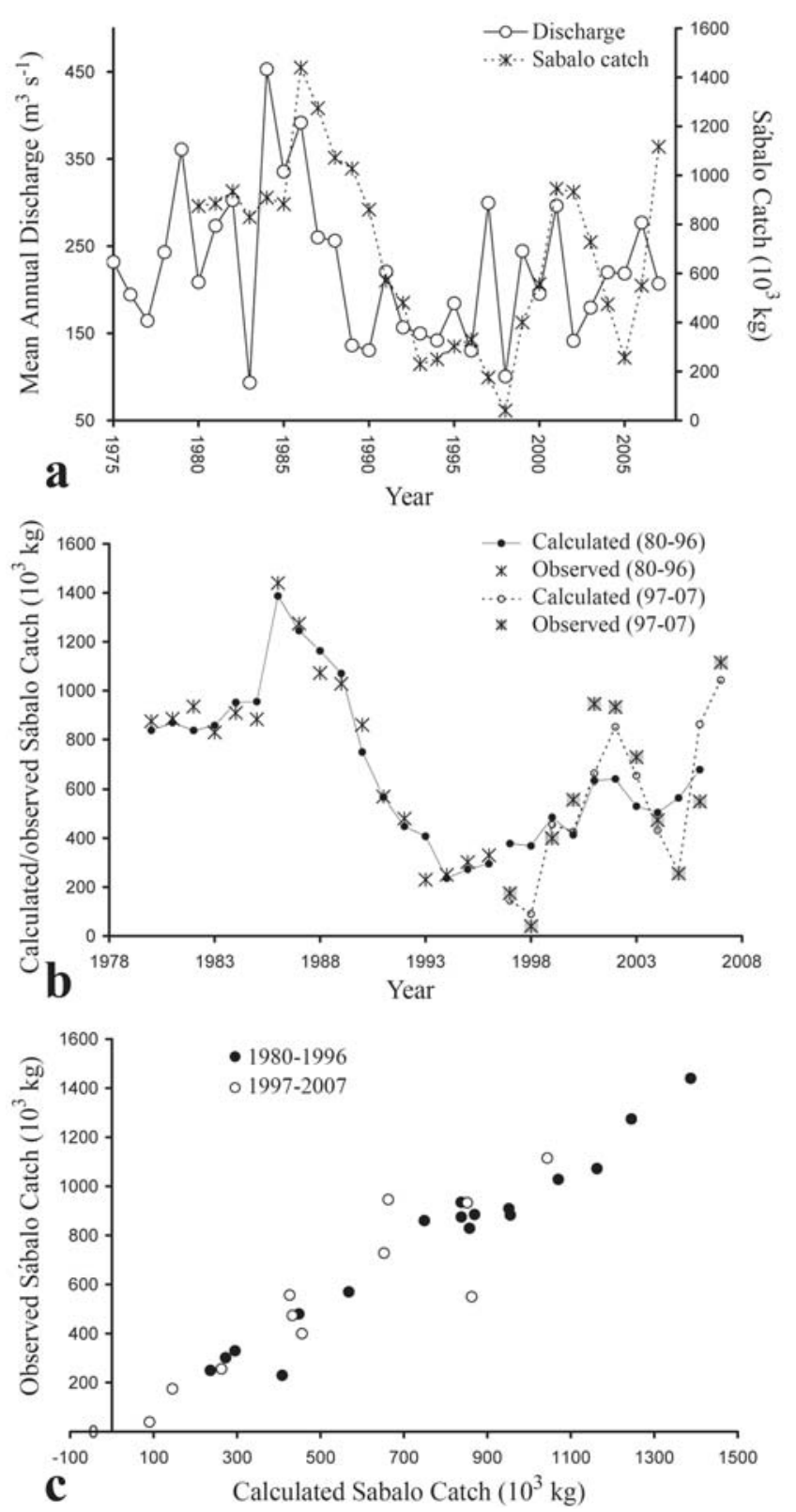

Fig. 5. (a) Mean annual discharge and Sábalo catches over the years in the Pilcomayo River near Villa Montes. (b) Calculated and observed Sábalo catches based on the data presented in Fig. 4a. Correlations were obtained by stepwise multiple linear regression with backward selection (SPSS v. 15.0). The river discharge of the seven preceding years (Y1-Y7) plus the current year (Y0) were used in the analyses. The solid line is based upon the years 1980-2006. The dashed line is based upon the years 1997-2007. (c) Observed Sábalo catches plotted against the calculated Sábalo catches for the years 1980-1996 and 19972006. Data of Sábalo catches and mean river discharges were obtained from Proyecto Pilcomayo (Tarija, Bolivia).

be explained by past river discharges (Fig. 5b). Apparently the memory effect has gone and the system has become less stable. An explanation might be provided by water 
Table 1. Results of the stepwise multiple linear regression with backward selection (SPSS v. 15.0). The seven preceding years (Y1-Y7) plus the current year (Y0) were included in the analyses as dependent variables. For each model (step) the unstandardized coefficients with degree of significance and the basic statistics are presented. Sábalo catch was the dependent variable. The criterion for the probability of F-to-remove was $\geq .100$ ). Dependent variable: $\mathrm{CATCH}$.

\begin{tabular}{|c|c|c|c|c|c|c|c|}
\hline \multirow{2}{*}{$\begin{array}{c}1980-1996 \\
\text { Model }\end{array}$} & \multicolumn{7}{|c|}{$1997-2007$} \\
\hline & & Coeff. & Sig. & Model & & C oeff. & Sig. \\
\hline \multirow[t]{11}{*}{1} & (Constant) & -642.8867 & 0.0015 & 1 & $($ Constant $)$ & -3680.2587 & 0.0398 \\
\hline & Y 0 & 0.9180 & 0.0075 & & Y0 & 4.8059 & 0.0741 \\
\hline & Y 1 & 1.4473 & 0.0003 & & Y1 & 6.5280 & 0.0451 \\
\hline & Y 2 & 1.6874 & 0.0002 & & $\mathrm{Y} 2$ & 7.0114 & 0.0358 \\
\hline & Y 3 & 0.5445 & 0.0611 & & Y3 & 5.6298 & 0.0504 \\
\hline & Y 4 & 0.7047 & 0.0227 & & Y4 & 0.9222 & 0.4715 \\
\hline & Y 5 & 0.8660 & 0.0084 & & Y5 & -1.6452 & 0.3072 \\
\hline & Y 6 & 0.0592 & 0.8180 & & Y6 & -1.5158 & 0.3306 \\
\hline & Y7 & -0.3191 & 0.2408 & & Y7 & -1.3641 & 0.3850 \\
\hline & Adjusted $\mathrm{R}^{2}$ & F & Sig. & & Adjusted $\mathrm{R}^{2}$ & $\mathrm{~F}$ & Sig. \\
\hline & 0.936 & 30.039 & 0.0000 & & 0.751 & 4.771 & 0.185 \\
\hline \multirow[t]{10}{*}{2} & (Constant) & -630.9254 & 0.0005 & 2 & $($ Cons $\tan t)$ & -3471.2524 & 0.0152 \\
\hline & Y 0 & 0.9294 & 0.0038 & & Y0 & 4.9783 & 0.0327 \\
\hline & Y 1 & 1.4484 & 0.0001 & & Y1 & 6.5119 & 0.0180 \\
\hline & Y 2 & 1.6715 & 0.0001 & & $\mathrm{Y} 2$ & 7.0206 & 0.0127 \\
\hline & Y3 & 0.5429 & 0.0473 & & Y3 & 5.4085 & 0.0223 \\
\hline & Y 4 & 0.7199 & 0.0118 & & Y5 & -1.8837 & 0.1956 \\
\hline & Y 5 & 0.8691 & 0.0050 & & Y6 & -1.3832 & 0.3100 \\
\hline & Y7 & -0.3193 & 0.2130 & & Y7 & -1.4212 & 0.3175 \\
\hline & Adjusted $\mathrm{R}^{2}$ & F & Sig. & & Adjusted $\mathrm{R}^{2}$ & F & Sig. \\
\hline & 0.942 & 38.341 & 0.0000 & & 0.770 & 5.774 & 0.089 \\
\hline \multirow[t]{24}{*}{3} & (Constant) & -712.1921 & 0.0001 & 3 & $($ Cons $\tan t)$ & -3503.7840 & 0.0085 \\
\hline & Y 0 & 0.8967 & 0.0048 & & Y0 & 4.7854 & 0.0256 \\
\hline & Y 1 & 1.4495 & 0.0001 & & Y1 & 6.2577 & 0.0121 \\
\hline & Y2 & 1.6847 & 0.0001 & & $\mathrm{Y} 2$ & 6.7254 & 0.0077 \\
\hline & Y3 & 0.6109 & 0.0291 & & Y3 & 4.8518 & 0.0160 \\
\hline & Y4 & 0.7215 & 0.0126 & & Y5 & -2.1053 & 0.1486 \\
\hline & Y 5 & 0.8148 & 0.0071 & & Y6 & -0.9515 & 0.4481 \\
\hline & Adjusted $\mathrm{R}^{2}$ & F & Sig. & & Adjusted $\mathrm{R}^{2}$ & F & Sig. \\
\hline & 0.938 & 41.153 & 0.0000 & & 0.745 & 5.866 & 0.054 \\
\hline & & & & 4 & $($ Cons $\tan t)$ & -3473.6813 & 0.0044 \\
\hline & & & & & Y0 & 4.4474 & 0.0178 \\
\hline & & & & & Y1 & 5.7420 & 0.0061 \\
\hline & & & & & Y2 & 6.1947 & 0.0031 \\
\hline & & & & & Y3 & 4.7296 & 0.0098 \\
\hline & & & & & Y5 & -1.5774 & 0.1639 \\
\hline & & & & & Adjusted $\mathrm{R}^{2}$ & F & Sig. \\
\hline & & & & & 0.760 & 7.329 & 0.024 \\
\hline & & & & 5 & $($ Constant) & -3260.3305 & 0.0059 \\
\hline & & & & & Y0 & 3.6430 & 0.0342 \\
\hline & & & & & Y1 & 4.9430 & 0.0093 \\
\hline & & & & & $\mathrm{Y} 2$ & 6.0998 & 0.0035 \\
\hline & & & & & $\mathrm{Y} 3$ & 3.9793 & 0.0167 \\
\hline & & & & & Adjusted $\mathrm{R}^{2}$ & $\mathrm{~F}$ & Sig. \\
\hline & & & & & 0.698 & 6.657 & 0.021 \\
\hline
\end{tabular}

management changes. Since the end of the 1990's, more water was directed, towards Argentinean territory causing significant changes in hydrological processes in the lower catchment area. This caused a rapid siltation of parts of the river bed and breakthroughs of river banks, resulting in the inundation of new areas within the floodplain, while formerly flooded areas became devoid of water (Smolders, 2006).

Smolders et al. $(2000,2002)$ demonstrated that since the mid 1970's the mean annual discharge of the Pilcomayo River is closely related to the large-scale climatic "El Niño" Southern Oscillation (ENSO) system. ENSO is known to influence river discharges throughout the world by its influence on rainfall patterns (Depetris et al., 1996; Stone et al., 1996; Poveda \& Mesa, 1997; Sun \& Furbish, 1997; Puckridge et al., 2000;
Camilloni \& Barros, 2003). The two worst "El Nino" years of the last thirty years, 1982/1983 and 1997/1998, were characterized by very low mean discharges in the Pilcomayo River (Fig. 4). In the 1990's, five consecutive years with relatively low or very low mean river discharges coincided with a strong decline in the fish catches in Villa Montes. The low river discharges in the first half of the nineties also coincided with a five-year period in which the SOI (Southern Oscillation Index) was consistently low. Some consider this period as the longest "El Niño" event on record (Trenberth \& Hoar, 1996). In 2007 the Sábalo catches were comparable to the catches before the "El Niño" event (Fig. 5b).

It is remarkable, however, that river discharge values were comparably low in the 1960's although in these years no alarming 
reports of low numbers of Sábalo have been reported for the river (Fig. 4). We will come back to this in the following section.

\section{Stream self-blockage/megafan river behaviour}

A major problem in the Pilcomayo River are the high erosion rates in the Andean region. The mean sediment load of the Pilcomayo River $\left(10.6 \mathrm{~g} \mathrm{~L}^{-1}\right)$ is amongst the highest in the world (Guyot et al., 1990; Iriondo, 1993; Smolders et al., 2002; Depetris et al., 2003; Wilkinson et al., 2006). The main cause of the strong erosion is the susceptibility of the local geological formations to erosion because of their small particle size (Iriondo, 1993). Guyot et al. (1990) calculated that the mean erosion rate for the catchment area upstream of Villa Montes amounted to $890 \mathrm{t} \mathrm{km}^{-2} \mathrm{y}^{-1}$ for the period between 1979 and 1982. It should be realized that the mean annual amount of sediment transported by the river is sufficient to cover as much as 5000 ha of land with one meter of sediment. The sedimentation of this material provokes silting up as well as diversion of the river bed.

Thus, huge amounts of sediment are transported to the lower reaches of the river in the Chaco plain. In this region the suspended sediment is deposited creating an alluvial fan with a total surface area of $210,000 \mathrm{~km}^{2}$ (Iriondo, 1993). It is assumed that the current situation of erosion and sedimentation has remained unchanged since $1000 \mathrm{BP}$ (Iriondo, 1993). The fan has formed because the river has changed its course several times. During the last centuries, the river discharged into a tectonic depression called Estero Patiño (Cordini, 1947), located $250 \mathrm{~km}$ upstream from the Paraguay River. This depression gradually filled up with sediment until it had become more or less completely silted up in the mid 1940's (Pool et al., 1993). Then the river started to fill up its own river channel, resulting in a gradual retreat of the river. The existence in the region of many fully silted up paleochannels of the Pilcomayo demonstrates that historically the river has frequently changed its course due to this kind of sedimentation processes (Iriondo, 1993; Pool et al., 1993). As a consequence, the Sábalo population of the Pilcomayo has become more or less completely isolated from the populations in the La Plata basin.

The overflowing water started to form new swampy areas (Wilkinson et al., 2006) (Fig. 6). The point where the river "disappears" (choke point; Fig. 6) has been moving upstream rapidly ever since, a process called endpoint recession. The amount of sediment transport strongly depends on river discharge (Smolders et al., 2002). Since the mid-1970's high river discharges resulted in high annual sediment transports and to a rapid increase of the endpoint recession rate of the river bed (Smolders et al., 2002). The geomorphologic changes which resulted from the high sediment deposition rates in de Pilcomayo floodplain, also seem to have changed the relationship between river discharge and fish production, in the sense that nowadays higher discharges are required to produce the same amount of fish compared to the 1960's (see Fig. 5). Since the early 1990's a further silting up of the river bed was more or less successfully prevented by the construction of channels that try to divide equal parts of the river water between Paraguay and Argentina.

The connectivity between the main river and flood plain areas, can be very dynamic, a phenomenon which seems to play an even more important role since the late 1990's. Due to a less consistent maintenance by the Paraguayan channel, relatively more water (and thus sediment) was directed, towards Argentinean territory. This resulted locally in a rapid siltation of the river bed and breakthroughs of river banks, resulting in the inundation of new areas within the floodplain (Fig. 6). Such events may in some years strongly increase the connectivity, with areas rich in young Sábalo, resulting in relatively high numbers of migrating Sábalo in the dry season. For instance, reconnection of formerly isolated lakes, liberating fish that had been isolated in these pools, may have played an important role since 1998 and explain the underestimation of the Sábalo catches based on the linear regression established from catches before that period (Fig. 5b).

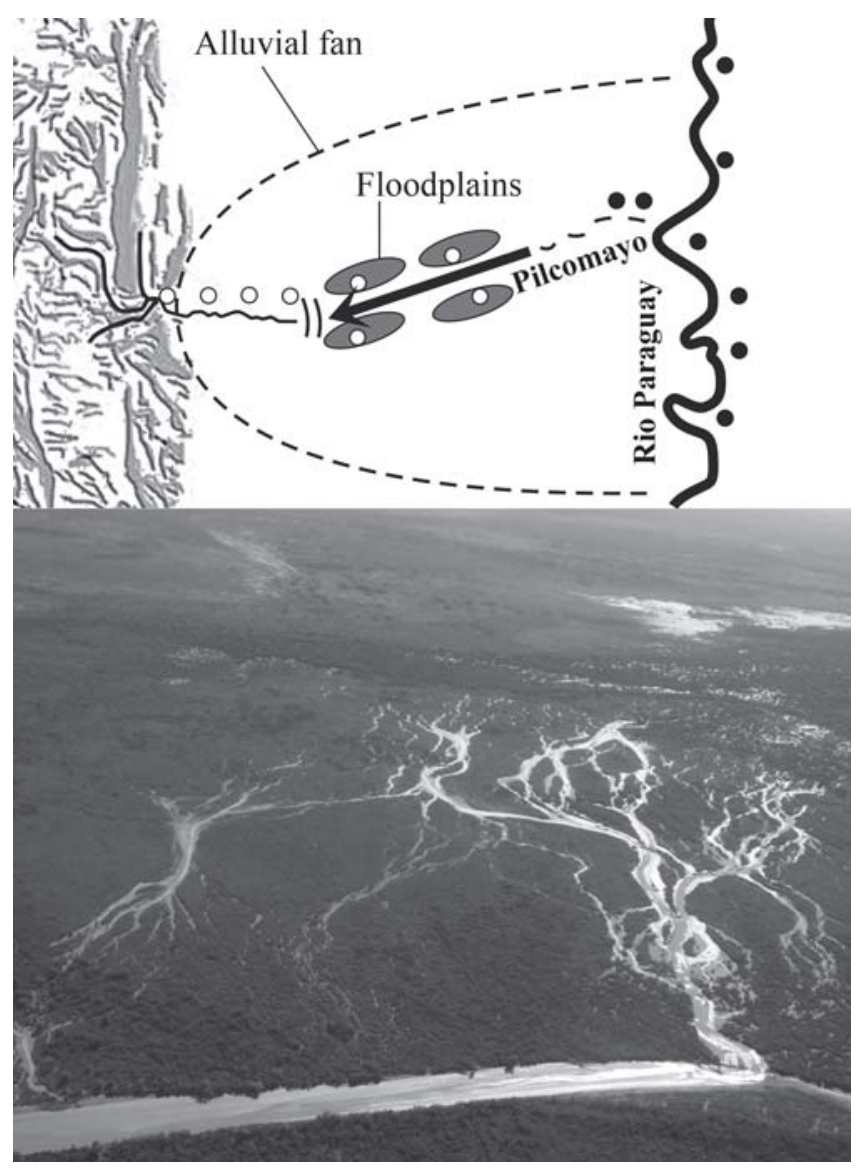

Fig. 6. Above: Retreat of the Pilcomayo River and dynamic creation of new flood plains due to self-blockage (silting up) of the river channel. This caused a retreat of hundreds of kilometers of the choke point in a few decades (indicated by the black arrow) and an upstream migration of the flood plains. Bullets indicate migrating Sábalo population in the Pilcomayo River (white) and Sábalo population in the La Plata basin (black). Below: Breakthrough of Pilcomayo River bank inundating new areas in the Chaco floodplain area. 


\section{Conclusions and perspectives}

It is generally assumed that the contamination of the Pilcomayo River is responsible for the decline of the Sábalo population during the 1990's (e.g. Medina Hoyos, 1998). However, our results show that we can quite well explain the historic and current Sábalo catches in the river by the hydrodynamic processes in the river basin.

The decline of the Sábalo in the 1990's seemed to be caused by the decreased river discharges in these years resulting in smaller inundated areas during rainy season floods and thereby in a decreased surface of the feeding grounds for the Sábalo. The decreased river discharges can be attributed to the 90-95 El Niño event, one of the severest on record. Over-exploitation of the fish stock in these years has possibly co-contributed to this decline of the Sábalo. This river discharge hypothesis was confirmed by observations in recent years showing a recovery of the Sábalo catches in Villa Montes as a result of the reestablished river discharges since the late 1990's. The connectivity (continuity) between the main river channel and flood plain areas, are also of great importance and very probably play an even more important role since the late 1990's.

At the moment a master plan is being developed for the entire Pilcomayo basin (Coccato et al., 1999; Smolders, 2006). The enormous amounts of sediment that are transported every year to the lower reaches of the river provoke enormous problems. The resulting unpredictable desiccation and inundation can harass the human population that are planned to inhabit these areas in the near future. However, proposed measures meant to tackle the sedimentation processes in the lower reaches of the Pilcomayo River may have adverse effects on Sábalo populations. One of the measures being considered is the construction of a transversal dam a few hundred kilometers downstream of Villa Montes. This dam should retain an important part of the sediment load and also divide the water equally between Paraguay and Argentina. It is clear that such a measure would strongly affect flood-plain dynamics in the lower reaches and certainly the connectivity between the middle and the lower reaches of the river, and will thus strongly affect Sábalo catches in Bolivia. An alternative for such a dam is the construction of a series of reservoirs upstream of Villa Montes. These reservoirs should contain the sediment load of the river and would enable the regulation of the river discharge throughout the year. The construction of reservoirs in the middle range of the river will also have a negative effect on fish migration and river dynamics but moreover would strongly affect the intra-annual variation of stream velocity and total dissolved solid concentrations of the river water. This might affect the timing of the reproduction and also the distribution of alevins and eggs within the Pilcomayo floodplains (Fig. 3).

For floodplain rivers irregular dynamic phenomena are essential for the ecosystem functioning. Hence, all measures to regulate those rivers must be considered as an unnatural disturbance from an ecological point of view (Bayley, 1991,
1995; Welcomme et al., 2006). The problems that occur in naturally functioning river floodplains are rarely real ecological problems but frequently based on social and economic demands that the river is required to satisfy. The establishment of large nature reserves in the area might prevent the further development of agricultural activities in the lower reaches of the Pilcomayo River and decrease the necessity to combat the highly irregular flooding events and deposition of sediments. Ecotourism may be an important alternative to the development of agricultural activities in this still largely pristine region.

Simple multiple linear regressions from limited time series can accurately predict mono-species catches from hydrological values (Fig. 5). Such equations can be used to predict periods of fish scarcity or abundance without the need for complex modeling. However, major environmental alterations, for instance produced by hydrological changes, will alter the relationship. Furthermore, the world-wide increasing abstraction of water for agriculture, growing numbers of dams and dikes and at the same time anthropogenic climate change by global warming and El Niño events may pose serious threats for freshwater fisheries in floodplain rivers by diminishing the amount of water reaching the floodplain areas.

\section{Literature Cited}

Agostinho, A. A. \& M. Zalewski. 1995. The dependence of fish community structure and dynamics on floodplain and riparian ecotone zone in Parana River, Brazil. Hydrobiologia, 303: 141148.

Araújo-Lima, C. A. R. M. \& E. C. Oliveira. 1998. Transport of larval fish in the Amazon. Journal of Fish Biology, 53: 297306.

Baldwin, D. S. \& A. M. Mitchell. 2000. The effects of drying and re-flooding on the sediment and soil nutrient dynamics of lowland river floodplain systems: a synthesis. Regulated Rivers: Research \& Management, 16: 457-467.

Bayley, P. B. 1973. Studies on the migratory characin, Prochilodus platensis Holmberg 1989, Pisces, Characoidei in the River Pilcomayo, South America. Journal of Fish Biology, 5: 25-40.

Bayley, P. B. 1991. The flood pulse advantage and the restoration of river-floodplain systems. Regulated Rivers: Research \& Management, 6: 75-86.

Bayley, P. B. 1995. Understanding large river-floodplain ecosystems. BioScience, 45: 153-158.

Bayo, V. \& E. Cordiviola de Yuan. 1996. Food assimilation of a neotropical riverine detritivorous fish, Prochilodus lineatus, studied by fatty acid composition (Pisces, Curimatidae). Hydrobiologia, 330: 81-88.

Benke, A. C., I. Chaubey, G. M. Ward \& E. L. Dunn. 2000. Flood pulse dynamics of an unregulated river floodplain in the southeastern U.S. coastal plain. Ecology, 81: 2730-2741.

Bonetto, A. A., W. Dioni \& C. Pignalberi. 1969. Limnological investigations on biotic communities in the middle Paraná river valley. Verhandlungen der Internationalen Vereinigung für Theoretische und Angewandte Limnologie, 17: 1035-1050.

Bowen, S. H. 1983. Detritivory in neotropical fish communities. Environmental Biology of Fishes, 9: 137-144. 
Bowen, S. H., A. A. Bonetto \& M. O. Ahlgren. 1984. Microorganisms and detritus in the diet of a typical neotropical riverine detritivore, Prochilodus platensis (Pisces: Prochilodontidae). Limnology and Oceanography, 29: 11201122.

Camilloni, I. A. \& V. R. Barros. 2003. Extreme discharge events in the Paraná River and their climate forcing. Journal of Hydrology, 278: 94-106.

Coccato, M., S. Fattorelli, F. Iranzo, J. Khobzi \& C. Pfeiff. 1999. Mision de asistencia a la direccion ejecutiva de la comision trinacional para la elaboration de un plan maestro de manejo integrado de la cuenca del Pilcomayo. Tarija, Comision Trinacional, 28p.

Cordini, R. I. 1947. Los ríos Pilcomayo en la región del Patiño. Buenos Aires, Anales de la Dirección Nacional de Geología y Minería - Tomo I, 82p.

Cordiviola de Yuan, E. 1992. Fish populations of lentic environments of the Paraná river. Hydrobiologia, 237: 159-173.

De Graaf, G. 2003. Dynamics of floodplain fisheries in Bangladesh, results of 8 years fisheries monitoring in the Compartmentalization Pilot Project. Fisheries Management Ecology, 10: 191-199.

Depetris, P. J., S. Kempe, M. Latif \& W. G. Mook. 1996. ENSO controlled flooding in the Paraná River (1904-1991). Naturwissenschaften, 83: 127-129.

Depetris, P. J., J. L. Probst, A. I. Pasquini \& D. M. Gaiero. 2003. The geochemical characteristics of the Paraná River suspended sediment load: an initial assessment. Hydrological Processes, 17: 1267-1277.

Edwards, R. 1996. Toxic sludge flows through the Andes. New Scientist, 152: 4.

Espinach Ros, A., S. Sverlijn, F. Amestoym \& M. Spinetti. 1998. Migration pattern of the Sábalo Prochilodus lineatus (Pisces, Prochilodontidae) tagged in the lower Uruguay River. Verhandlungen der Internationalen Vereinigung für Theoretische und Angewandte Limnologie, 26: 2234-2236.

Flecker, A. S. 1996. Ecosystem engineering by a dominant detritivore in a diverse tropical stream. Ecology, 77: 1845-1854.

Fugi, R., N. S. Hahn \& A. A. Agostinho.1996. Feeding styles of five species of bottom-feeding fishes of the high Paraná River. Environmental Biology of Fishes, 46: 297-307.

Garcia-Guinea, J. \& M. Huascar. 1997. Mining waste poisons river basin. Nature, 387: 118.

Godoy, M. P. 1959. Age, growth, sexual maturity, behavior, migration, tagging and transplantation of the curimbatá (Prochilodus scrofa Steindacher, 1881) of the Mogi Guassu river, São Paulo state, Brasil. Anais da Academia Brasileira de Ciências, 31: 447-477.

Gomes, L. C. \& A. A. Agostinho. 1997. Influence of the flooding regime on the nutritional state and juvenile recruitment of the curimba, Prochilodus scrofa, Steindachner, in upper Paraná River, Brazil. Fisheries Management Ecology, 4: 263-274.

Guerrero Hiza, M. A. 1998. Situación actual de la pesca del río Pilcomayo. Villa Montes, 52p.

Guyot, J. L., H. Calle, J. Cortes \& M. Pereira. 1990. Transport of suspended sediment and dissolved material from the Andes to the Rio de la Plata by the Bolivian tributaries of the Rio Paraguay (Ríos Pilcomayo and Bermejo). Hydrological Sciences - Journal des Sciences Hydrologiques, 35: 653-665.

Hostache, G., M. Pacal \& P. Plaquette. 1993. Reproductive seasonality through the evolution of the gonado-somatic index in Hoplosternum littorale (Siluriforme, Teleostei) from French Guyana. Aquatic Living Resources, 6: 155-162.
Hudson-Edwards, K. A., M. G. Macklin, J. R. Miller \& P. J. Lechler. 2001. Sources, distribution and storage of heavy metals in the Río Pilcomayo, Bolivia. Journal of Geochemical Exploration, 72: $229-250$.

Iriondo, M. 1993. Geomorphology and late Quaternary of the Chaco (South America). Geomorphology, 7: 289-303.

Junk, W. J., P. B. Bayley \& R. E. Sparks. 1989. The flood pulse concept in river-floodplain systems. Canadian Journal of Fisheries and Aquatic Sciences, 106: 469-487.

Kirschbaum, F. 1979. Reproduction of the weakly electric fish Eigenmannia virescens (Rhamphichtyidae, Teleostei) in captivity. I. Control of gonadal recrudescence and regression by environmental factors. Behavioral Ecology and Sociobiology, 4 : 331-355.

Krykhtin, K. L. 1975. Causes of periodic fluctuations in the abundance of the non-anadromous fishes of the Amur river. Journal of Ichthyology, 15: 826-829.

Laë, R. 1992. Effects of hydrology on the evolution of the fisheries of the central delta of the Niger river from 1966 to 1989. Aquatic Living Resources, 5: 115-126.

Lopes, C. A., E. Benedito-Cecilio \& L. A. Martinelli. 2007. Variability in the carbon isotope signature of Prochilodus lineatus (Prochilodontidae, Characiformes) a bottom-feeding fish of the Neotropical region. Journal of Fish Biology, 70: 1649-1659.

Lucas, M. \& E. Barras. 2001. Migration of freshwater fishes. Oxford, Blackwell Science, 420p.

Medina Hoyos, R. I. 1998. Lineamentos para la planificación estratégica de la descontaminación y sostenibilidad hídrica del Pilcomayo. Tarija, Foro Tarijeño sobre Medio Ambiente y Desarrollo.

Miller, J. R., P. J. Lechler, K. A. Hudson-Edwards \& M. G. Macklin. 2002. Lead isotope fingerprinting of heavy metal contamination, Rio Pilcomayo basin, Bolivia. Geochemistry: Exploration, Environment, Analysis, 2: 225-233.

Mochek, A. D. \& D. S. Pavlov. 1998. The ecology of Sábalo Prochilodus lineatus (Curimatidae, Characoidei) of the Pilcomayo River (South America). Journal of Ichthyology, 38 : 28-36.

Moses, B. S. 1987. The influence of flood regime on fish catch and fish communities of the Cross River floodplain ecosystem, Nigeria. Environmental Biology of Fishes, 18: 51-65.

Paugy, D. 2002. Reproductive strategies of fishes in a tropical temporary stream of the Upper Senegal basin: Baoulé River in Mali. Aquatic Living Resources, 15: 25-35.

Payne, A. I. \& M. J. Harvey. 1989. An assessment of the Prochilodus platensis Holmberg population in the Pilcomayo river fishery, Bolivia using scale-based and computer-assisted methods. Aquaculture and Fisheries Management, 20: 253-248.

Pool, M., E. Usai \& J. Baas. 1993. Estudio del Rio Pilcomayo. Brussels, EURAGRI Temporary Association.

Poveda, G. \& O. J. Mesa. 1997. Feedbacks between hydrological processes in tropical South America and large-scale oceanatmospheric phenomena. Journal of Climate, 10: 2690-2702.

Puckridge, J. T., K. F. Walker \& J. F. Costelloe. 2000. Hydrological persistence and the ecology of dryland rivers. Regulated Rivers: Research \& Management, 16: 385-402.

Ramnarine, I. W. 1995. Induction of nest building and spawning in Hoplosternum littorale. Journal of Fish Biology, 47: 555-557.

Smolders, A. J. P. 2006. Una evaluación de la situación Ictícola y lineamientos para el manejo de los humedales del río Pilcomayo. Comisión Trinacional para la Cuenca del río Pilcomayo, 222p. 
Smolders, A. J. P., M. A. Guerrero Hiza, G. van der Velde \& J. G. M. Roelofs. 2002. Dynamics of discharge, sediment transport, heavy metal pollution and Sábalo (Prochilodus lineatus) catches in the lower Pilcomayo river (Bolivia). River Research \& Applications, 18: 415-427.

Smolders, A. J. P., K. A. Hudson-Edwards, G. van der Velde \& J. G. M. Roelofs. 2004. Controls on water chemistry of the Pilcomayo river (Bolivia, South-America). Applied Geochemistry, 19: 1745-1758.

Smolders, A. J. P., R. A. C. Lock, G. van der Velde, R. I. Medina Hoyos \& J. G. M. Roelofs. 2003. Effects of mining activities on heavy metal concentrations in water, sediments and macroinvertebrates in different reaches of the Pilcomayo river, South America. Archives of Environmental Contamination and Toxicology, 44: 314-323.

Smolders, A. J. P., G. van der Velde, J. G. M. Roelofs \& M. A. Guerrero Hiza. 2000. El Niño caused collapse of the Sábalo fishery (Prochilodus lineatus, Pisces: Prochilodontidae) in a South American river. Naturwissenschaften, 87: 30-32.

Stone, R. C., G. L. Hammer \& T. Marcussen. 1996. Prediction of global rainfall probabilities using phases of the Southern Oscillation Index. Nature, 384: 252-255.

Sun, H. \& D. J. Furbish. 1997. Annual precipitation and river discharges in Florida in response to El Niño and La Niña surface temperature anomalies. Journal of Hydrology, 199: 74-87.

Taylor, B. W., A. S. Flecker \& R. O. Hall Jr. 2006. Loss of a harvested fish species disrupts carbon flow in a diverse tropical river. Science, 313: 833-836.

Trenberth, K. E. \& T. J. Hoar. 1996. The 1990-1995 El NiñoSouthern Oscillation event: longest on record. Geophysical Research Letters, 23: 57-60.

Ward, J. V. \& J. A. Stanford. 1995. Ecological connectivity in alluvial river ecosystems and its disruption by flow regulation. Regulated Rivers: Research \& Management, 11: 105-119.

Welcomme, R. L. 1979. The Fisheries Ecology of Floodplain Rivers. London, Longman, 317p.

Welcomme, R. L. 1995. Relationships between fisheries and the integrity of river systems. Regulated Rivers: Research \& Management, 11: 121-136.

Welcomme, R. L., C. Bene, C. A. Brown, A. Arthington, P. Dugan, J. M. King \& V. Sugunan. 2006. Predicting the water requirements of river fisheries. In: Verhoeven J. T. A., B. Beltman, R. Bobbink \& D. F. Whigham (Eds.). Wetlands and natural resource management. Springer Verlag Berlin Heidelberg. Ecological Studies, 190: 123-154.

Welcomme, R. L. \& D. Hagborg. 1977. Towards a model of a floodplain fish population and its fishery. Environmental Biology of Fishes, 2: 7-24.

Wilkinson, M. J., L. G. Marshall \& J. G. Lundberg. 2006. River behaviour on megafans and potential influences on diversification and distribution of aquatic organisms. Journal of South American Earth Sciences, 21: 151-172.

Winemiller, O. 1989. Patterns of variation in life history among South American fishes in seasonal environments. Oecologia, 81: 225-241. 